\title{
Some Geotechnical Behaviour of Silty Clay Improved with Lime and Nanolime
}

\author{
Mohd Raihan Taha ${ }^{1,2, *}$, Panbarasi Govindasamy ${ }^{3}$, and Jamal Alsharef ${ }^{1}$ \\ ${ }^{1}$ Universiti Kebangsaan Malaysia (UKM), Department of Civil and Structural Engineering, 43600, Malaysia \\ ${ }^{2}$ Universiti Kebangsaan Malaysia (UKM), Institute for Environment and Development (LESTARI), 43600, Malaysia \\ ${ }^{3}$ Politeknik Ungku Omar, Department of Civil Engineering, 31400, Malaysia
}

\begin{abstract}
Chemical stabilization involves application of chemical admixtures to improve the behaviour of soil. Thus, this study was carried out to validate the effectiveness of nanolime additives as soil stabilizer. Lime and nanolime were chosen as additive to investigate its effect on some geotechnical properties of clayey soil. The soil was mixed with the additives ranging from 0.2 to $1.0 \%$ by dry weight of soil. The results indicate that adding a low percentage of nanolime can lead to a noticeable reduction in soil plasticity. It is found that a considerable improvement in soil compaction results was achieved with nanolime compared with lime. Nanolime shows superiority in soil improvement compared with lime even at the dosage of $0.5 \%$. Chemical reactions between the calcium oxides and dissolved silica present in the soil mineral produced calcium silicate hydrate (CSH), where the morphology of this product can be recognized under FESEM test. The results indicate that the stabilization mechanism of treated soil involved flocculation and agglomeration of soil particles by $\mathrm{Ca}^{+2}$ which bridges the negatively charged clay particles The existence of even a minute amount of nanolime can result in extraordinary effects on the engineering properties of soil.
\end{abstract}

\section{Introduction}

Chemical stabilization involves application of chemical admixtures to improve the behaviour of soil. It is used to improve soil workability, reduce plasticity and shrinkswell potential. If clays are dispersive, it is used to flocculate the particles. When clays are difficult to compact, chemicals can be added to slightly disperse their particles and assist the process [1]. Chemical stabilization of clayey soils by admixing it with stabilizers such as lime and cement aim to increase strength, reduce deformability, provide volume stability (control shrinkage and swelling), reduce permeability; reduce erodibility, increase durability, or control variability of natural soils [2].

In recent years, application of nano materials in engineering studies has attracted the interest to researcher from all over the world. Nano particles are referred as nano crystals due to its crystalline form. The transition from micro particles to nano particles can attribute to positive changes in physical properties. This is because of the increase in ratio of surface area and changes in volume. Due to the large surface area of nano particles, a lot of interactions occur between intermixed materials such as nano composites which lead to an increase in strength of the materials [3].

Laboratory experiments were presented to study the fundamental geotechnical properties of mixtures of natural soils and its' product after ball milling operation
[4]. The product after ball milling process was termed nano-soil herein. The plastic limit (PL) and liquid limit (LL) of soil mixtures consisting of $98 \%$ original soil and $2 \%$ nano-soil increased compared to the values of $100 \%$ original soil. Since the increase in the LL was less that of $\mathrm{PL}$, it reduced the plasticity index (PI) which is advantageous in many geotechnical constructions. These results showed that a small amount of these milled particles or nano-soil can provide significant improvement in the geotechnical properties of soil.

\section{Materials}

\subsection{Properties of original soil}

The original soil sample was collected from the hilly area of Universiti Kebangsaaan Malaysia (UKM). It was collected at shallow depth after removing the top $0.5 \mathrm{~m}$ depth of ground surface. The natural water content was $22.8 \%$ while the maximum dry density $\left(\gamma_{\mathrm{dmax}}\right)$ and optimum water content $\left(\omega_{\mathrm{opt}}\right)$ were $1.87 \mathrm{~g} / \mathrm{cm}^{3}$ and $15.6 \%$, respectively. According to the unified soil classification system (USCS), the tested soil was classified under group symbol of SC. The soil contained no gravel. Meanwhile, the fraction of sand, silt and clay are $57.5,22.5$, and $20 \%$, respectively. Figure 1 presents the distribution of particle size of original soil.

* Corresponding author: profraihan@ukm.edu.my 


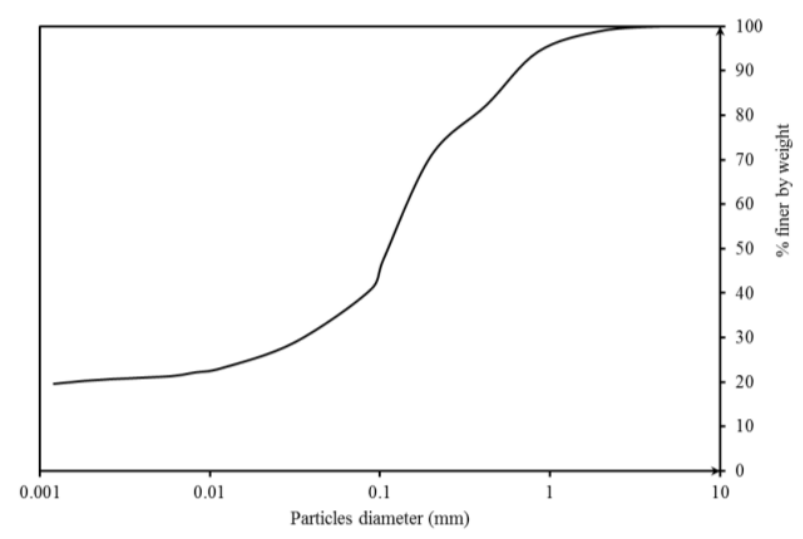

Fig. 1. Particles sizes distribution curve of original soil.

\subsection{Particle size of additives}

Table 1 shows the average size of particles and the crystal size of lime and nanolime obtained from the Field Emission Scanning Electron Microscope (FESEM) and X-ray Powder Diffraction (XRD) tests. The average size of lime particles is $621.12 \mathrm{~nm}$ while the nanolime is smaller than $27 \mathrm{~nm}$. Through the XRD test, the data was calculated using the Scherer formula to find the size of the crystal. The crystal size of lime is $75.44 \mathrm{~nm}$ and the nanolime is $19.36 \mathrm{~nm}$. Figure 2 and 3 shows the particle size measured using 'SmartTiff' software. Both images of the FESEM test were selected in the same magnification of $30.00 \mathrm{KX}$ for measurement of nanostructural size. This proves that nanolime particles are smaller than lime grains. It further supports that the materials in nanoscale dimensions include very small particles. Nano particles create a positive change in physical properties due to an increase in surface area ratio and change in volume.

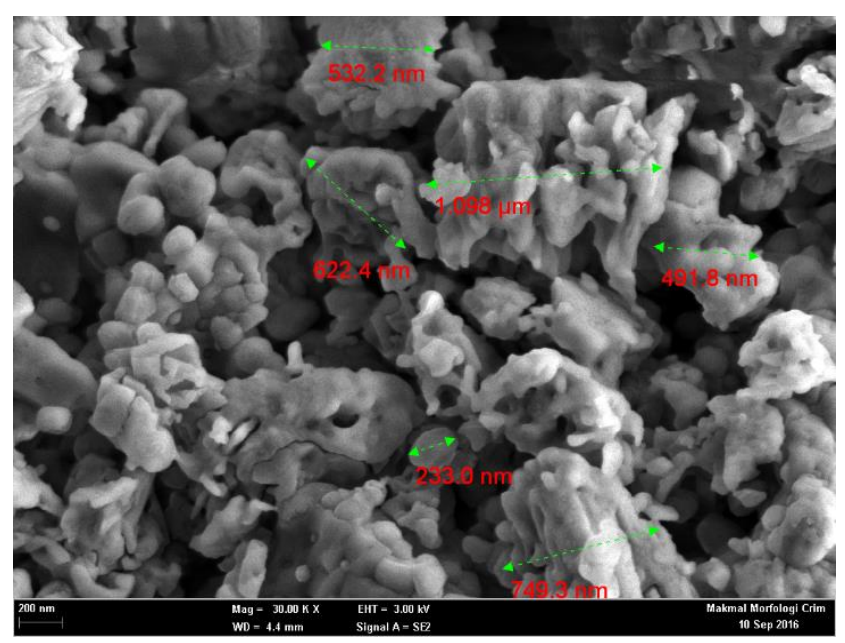

Fig. 2. Image of lime with the measurement of particle size (Mag: $30.00 \mathrm{KX}$ )

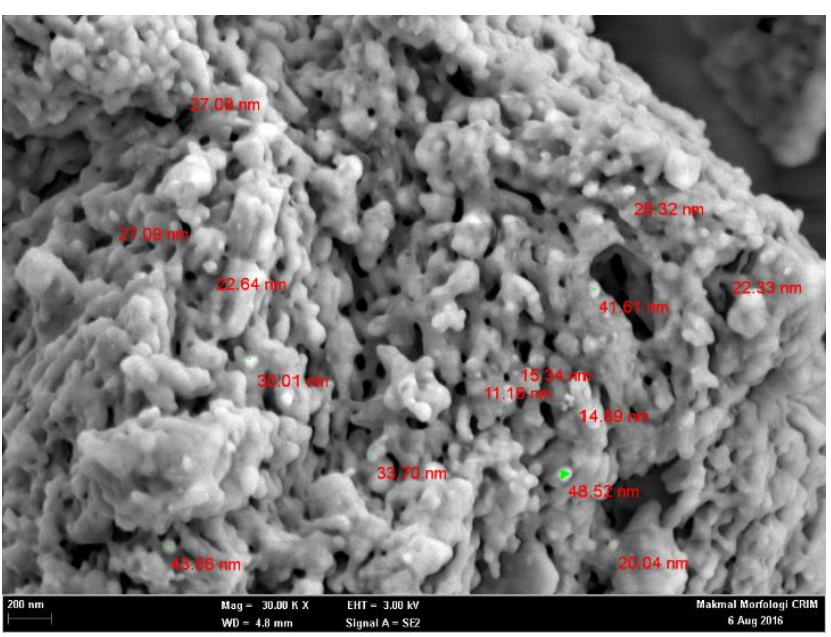

Fig. 3. Image of nanolime with the measurement of particle size (Mag: $30.00 \mathrm{KX}$ )

Table 1. Average size of particles and the crystal size of lime and nanolime

\begin{tabular}{|l|c|c|}
\hline & $\begin{array}{c}\text { FESEM test - } \\
\text { Average particle } \\
\text { size }\end{array}$ & $\begin{array}{c}\text { XRD test - } \\
\text { Crystal size }\end{array}$ \\
\hline Lime & $621.12 \mathrm{~nm}$ & $75.44 \mathrm{~nm}$ \\
\hline Nanolime & $27 \mathrm{~nm}$ & $19.36 \mathrm{~nm}$ \\
\hline
\end{tabular}

\subsection{Chemical characterization of soil and additives}

Lime and nanolime were the two additives used for this study. Lime powder was obtained from local market. Nanolime powder was imported from Strem Chemicals, Inc., Mulliken Way, Newburyport, Massachusetts, United States. The results of X-ray fluorescence (XRF) test for the additives are illustrated in Table 2. It can be seen that the nanolime has greater purity than the lime. A large trace of $\mathrm{CaO}$ was available in both grades, while lime contained a noticeable amount of $\mathrm{MgO}(1.75 \%)$ compared to $1.24 \%$ which was available in nanolime. Table 3 presents the chemical composition of original soil, where the silica and alumina were the main components and then iron oxide comes as a third most abundant component. 
Table 2. Chemical composition of lime and nanolime additives.

\begin{tabular}{llllllllllll}
\hline & $\mathrm{CaO}$ & $\mathrm{MgO}$ & $\mathrm{SO}_{3}$ & $\mathrm{SiO}_{2}$ & $\mathrm{Al}_{2} \mathrm{O}_{3}$ & $\mathrm{Fe}_{2} \mathrm{O}_{3}$ & $\mathrm{SrQ}$ & $\mathrm{Cl}$ & $\mathrm{K}_{2} \mathrm{O}$ & $\mathrm{ZnO}$ & $\mathrm{ZrO}_{2}$ \\
\hline Lime & $95.21 \%$ & $1.75 \%$ & $0.56 \%$ & $0.22 \%$ & $0.13 \%$ & $0.08 \%$ & $0.03 \%$ & $0.02 \%$ & $0.01 \%$ & -- & - \\
Nanolime & $97.22 \%$ & $1.24 \%$ & $0.02 \%$ & $0.47 \%$ & $0.09 \%$ & $0.07 \%$ & $0.03 \%$ & $0.01 \%$ & $0.01 \%$ & $48 \mathrm{ppm}$ & $12 \mathrm{ppm}$ \\
\hline
\end{tabular}

Table 3. Chemical composition of original soil.

\begin{tabular}{cccccccccc}
\hline $\mathrm{SiO}_{2}$ & $\mathrm{Al}_{2} \mathrm{O}_{3}$ & $\mathrm{Fe}_{2} \mathrm{O}_{3}$ & $\mathrm{TiO}_{2}$ & $\mathrm{~K}_{2} \mathrm{O}$ & $\mathrm{MgO}$ & $\mathrm{ZrO}_{2}$ & $\mathrm{SO}_{3}$ & $\mathrm{CaO}$ & Others \\
\hline $60.35 \%$ & $21.83 \%$ & $4.36 \%$ & $1.13 \%$ & $0.51 \%$ & $0.47 \%$ & $0.09 \%$ & $0.08 \%$ & $0.05 \%$ & $0.08 \%$ \\
\hline
\end{tabular}

\section{Sample preparations}

Samples prepared were original soil, soil mixed with lime and soil mixed with nanolime. The percentages of lime and nanolime mixed with soil were $0.2 \%, 0.3 \%$, $0.5 \%, 0.8 \%$ and $1 \%$ each. The dry original soil was mixed with lime or nanolime percentages and then the water was added to the mixture. In this method, mixing was carried out into two stages. Initially premix or hand mixed [5], the quantity of soil was divided into ten layers and each layer was sprayed with the required amount of additives. Each layer was mixed alone then put in the pot and then the mixture is mixed again by horizontal cylindrical mixer for at least 3 hours [6]. The dry mixtures in the pot were sprayed with the required amount of water during the mixing process. The type of water used for preparing samples was distilled water. This procedure was found to be the best method to obtain homogeneous samples since homogeneous colour was obtained after compaction.

\section{Results and Discussions}

\subsection{Consistency limits and soil workability}

Figure 4 till Fig 7 show the change in consistency limits for soil and additives for different curing periods. Generally, LL of treated soil showed considerable increment with increasing percentage of lime and nanolime. For curing period of 28 days, the LL increased up to $37 \%$ and $35.7 \%$ for soil-lime and soil-nanolime mixtures respectively compared with the original soil $(\mathrm{LL}=31 \%)$. With the addition of lime, $\mathrm{Ca}^{2+}$ ions were released into the pore fluid. Thus, the electrolyte concentration of the pore water increases and decreases the thickness of the diffuse double layer held on to the soil and leading to a lower liquid limit. Hence, the liquid limit behaviour of lime treated soil has three different phases. The first phase is the reduction in thickness of the diffuse double layer, which takes place quickly and leads to a lower liquid limit. The second phase is the increase in the liquid limit attributable to fabric changes giving rise to flocculated structures. The last phase is the pozzolanic reactions, producing water holding gelatinous materials, which enhances the liquid limit. Thus, under lime treatment, soils with high silica content were prone to increase in the LL. Moreover, increased duration of curing will enable prolonged pozzolanic reaction. This produces increased quantity of water which holds gelatinous products and results in a further increase in the LL.

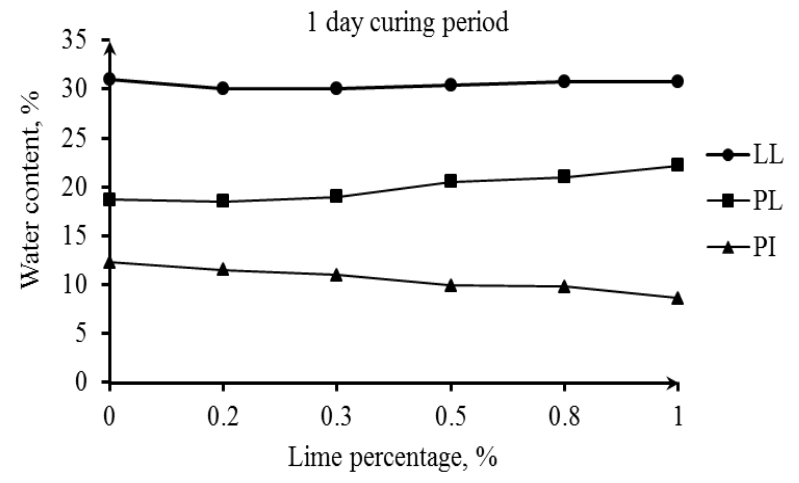

Fig. 4. Change in consistency limits with different lime contents after 1 day curing period.

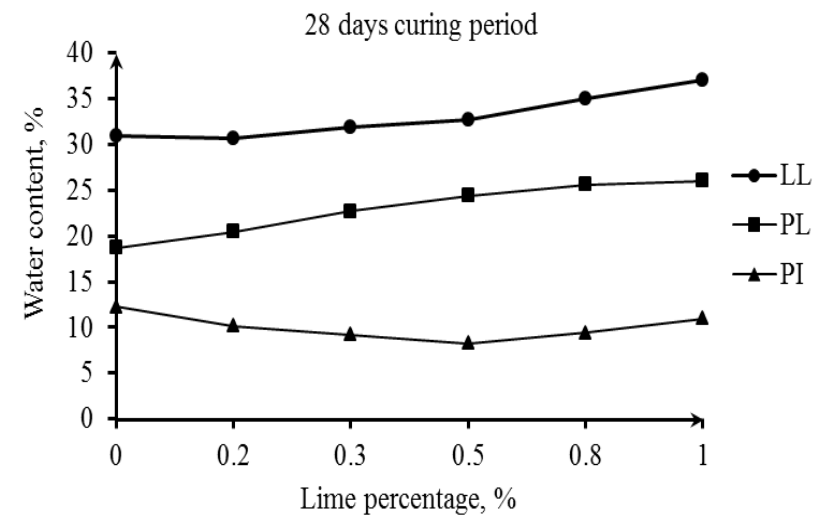

Fig. 5. Change in consistency limits with different lime contents after 28 days curing period.

The general trend of PL variation is directly proportional to the dosage of lime or nanolime and the curing period. The maximum values the PL attained for 
soil- $1 \%$ lime was $22.2 \%$ and $26 \%$ for 1 and 28 days curing period, respectively. These results indicate the increment of PL from the original reading which is $18.7 \%$. The PL is defined as a measure of cohesion of the soil particles against cracking when the soil is worked with [7]. The cohesion and, hence, the shear strength between the soil particles should be low enough that they can slide partly over one another at ease. However, at the same time, the interparticle shear strength should be high enough to hold the soil mass in the remoulded position. Hence, the PL is a measure of the water content of soil when it approaches a certain shear resistance. With the addition of lime, the thickness of the diffuse double layer decreases, which increases the charge concentration and thereby the viscosity of the pore fluid. Thus, the interparticle shear resistance increases, leading to a sharp increase in the PL. Moreover, for silica-rich soils, during a relatively long curing period, the PL continues to increase with an increase in the lime content. This phenomenon is attributed to the formation of the water holding CalciumSilicate-Hydrate (CSH) gel, a viscous material that allows the soil particles to maintain the moulded positions over a wider range of water content.

The behaviour is slightly different for nanolime, where the LL curve displayed rising trend for mixtures of nanolime doses greater than $0.2 \%$. LL for soil with $1 \%$ nanolime reached $32.6 \%$ at 1 day curing and increased to the maximum reading of $35.7 \%$ after 28 days curing. PL too increased gradually with increasing nanolime contents of $0.5 \%$ reaching to the maximum optimum water content of $23.3 \%$ at 1 day curing period and $27.2 \%$ after 28 days curing period. Nanoparticles have higher specific surface area and this will lead to a larger amount of water encompass the outer surface of particles and thereby it will increase liquid and plastic limits [8].

For PI, the tendency is reversed with respect to the percentage of lime or nanolime and curing period. A noticeable reduction in PI can be detected after first day of curing. However, the reduction is also significant after 28 days of curing period. An immediate decrease in the plasticity index was observed on addition of lime and nanolime because, as previously noted, immediately on addition of lime and nanolime, the LL and the PL increases. In addition, the nanolime has greater effect to reduce the PI of the treated soil. Compared with original soil $(\mathrm{PI}=12.3 \%)$, the minimum achieved values of PI were $8.6 \%$ and $8.3 \%$ for lime and $8.1 \%$ and $6.6 \%$ for nanolime for 1 and 28 days curing. PI reduction is certainly beneficial in geotechnical aspect of soil properties behaviour where it increases the soil workability and decreases the sensitivity of soil strength to the moisture. It also helps to reduce the shrinkage and swell potential of the soil [9].

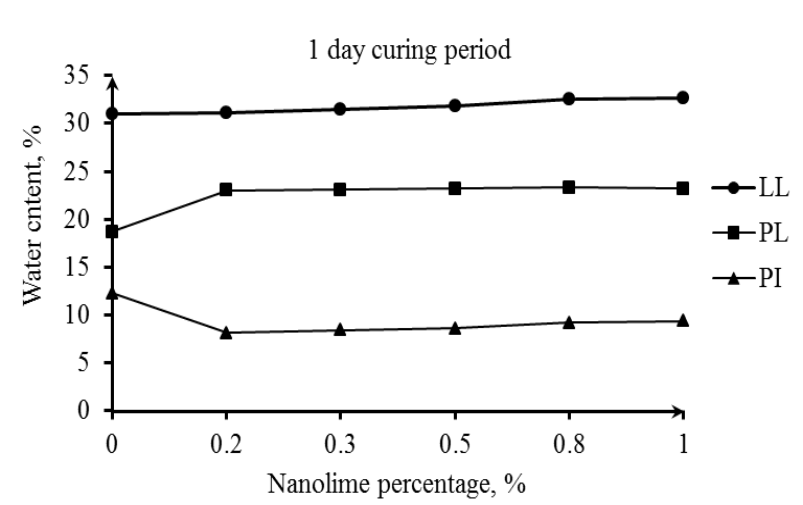

Fig. 6. Change in consistency limits with different nanolime contents after 1 day curing period.

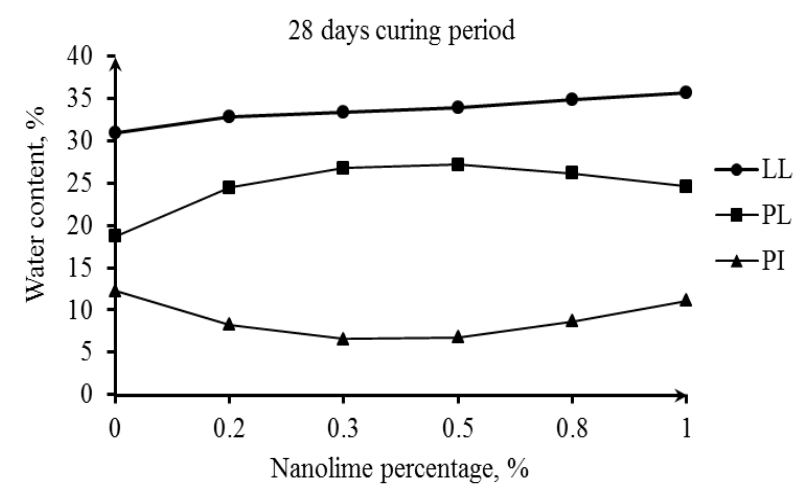

Fig. 7. Change in consistency limits with different nanolime contents after 28 days curing period.

\subsection{Impact on compaction parameters}

Figures 8 and 9 illustrate the change in compaction parameters for soil-lime and soil-nanolime mixtures, respectively after 1 day and 60 days curing period. Increasing the percentage of lime mixture led to a decrease in the dry density. The optimum water content suffers a reduction when the doses of lime were increased too. Soil-lime mixtures showed slight increment in maximum dry density when percentages of lime were increased to $0.8-1 \%$. The increase in the maximum dry density of the soil - lime mixtures was somehow less in the case of soil-nanolime. Meanwhile, soil-lime mixtures exhibited increment in optimum moisture content only at $0.5 \%$ to $0.8 \%$ after 1 day curing period and at $0.8 \%$ to $1 \%$ after 60 days curing period.

The maximum dry densities were 1.86 and 1.89 $\mathrm{g} / \mathrm{cm} 3$ for soil-lime and soil-nanolime mixtures, respectively after 1 day curing period. After 60 days, the value increased up to 1.88 and $1.93 \mathrm{~g} / \mathrm{cm} 3$ for soil-lime and soil-nanolime mixtures, respectively. The optimum water content for soil-lime and soil-nanolime were $16.2 \%$ and $17.2 \%$ after 1 day curing period and increased up to $16.5 \%$ for soil-lime and $17.8 \%$ for soilnanolime after 60 days curing period. Generally, the maximum dry density and optimum water content of the soil- nanolime mixtures were greater than that of original soil with maximum dry density of $1.87 \mathrm{~g} / \mathrm{cm} 3$ and $15.6 \%$ of optimum water content. The increase in maximum dry 
density is possibly due the fine particles of nanolime which acts as lubricating agent and filling the voids. The reason behind the optimum water content increase is related to the water consumption by hydration reaction. Moreover, the maximum dry density was obtained for soil mixed with only $0.3 \%$ nanolime at 1 day curing period and $0.5 \%$ nanolime at 60 days curing period. Higher optimum water content was also obtained at this nanolime content.
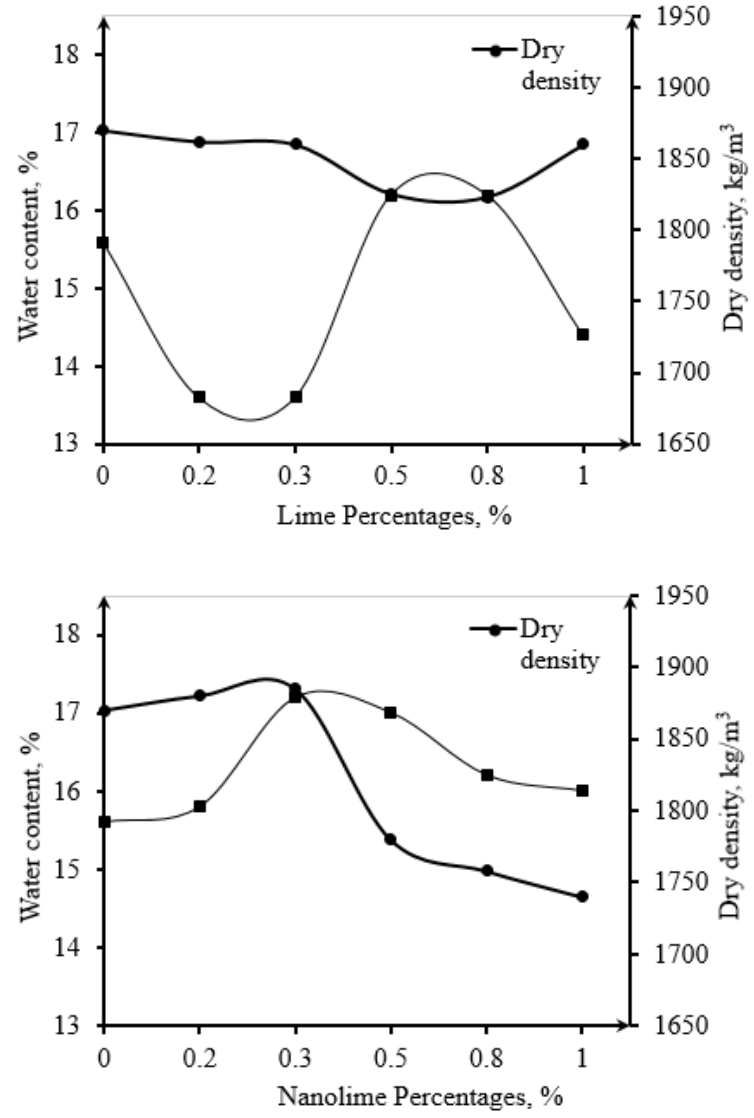

Fig. 8. Change in 1 day compaction parameters.
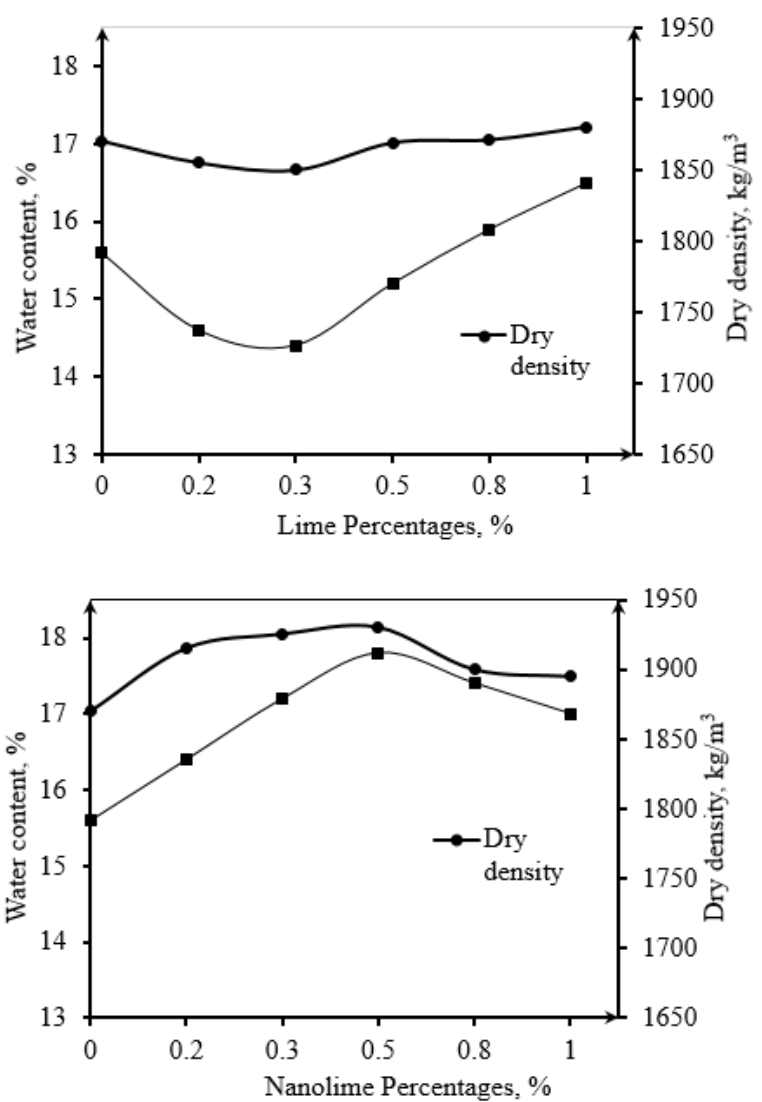

Fig. 9. Change in 60 days compaction parameters.

\subsection{Improvement mechanism investigation}

The Field Emission Scanning Electron Microscopy (FESEM) image of original soil is presented in figure 10 . Figure 11 shows the micrograph of soil mixed with $1 \%$ lime where it looks as self-assembly of flake likeparticles, while soil mixed with $1 \%$ nanolime shown in figure 12 looks like small flakes aggregated as ball like shape. The nanolime particles agglomerated more than that of lime. This is possibly because of van der waal forces developed between the nano particles. This morphology can be observed more clearly in figure 5 and figure 6 where the particles of soil-lime seemed to be discrete small particles in contrast to soil-nanolime particles which appeared to be fine particles agglomerated in ball like structure. 


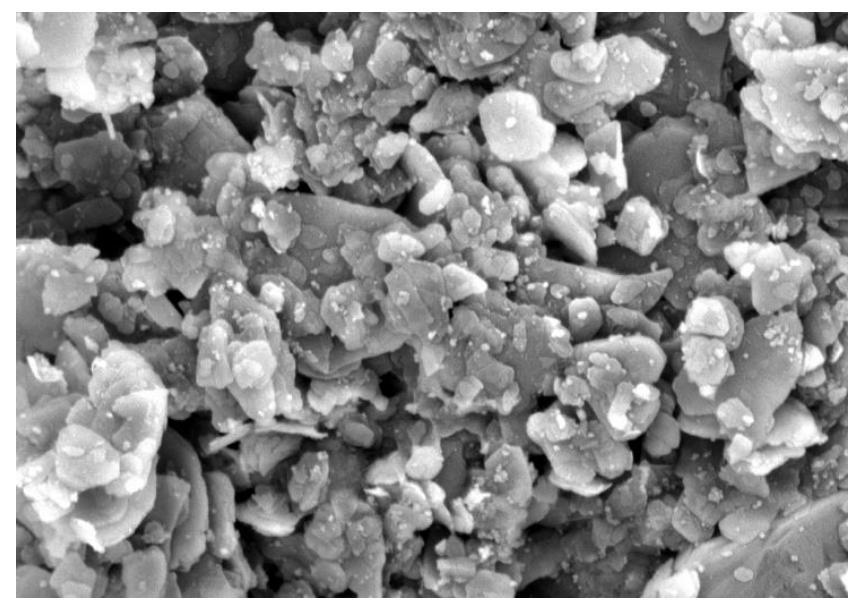

Fig. 10. FESEM micrograph of original soil: $\mathrm{Mag}=20.00 \mathrm{KX}$.

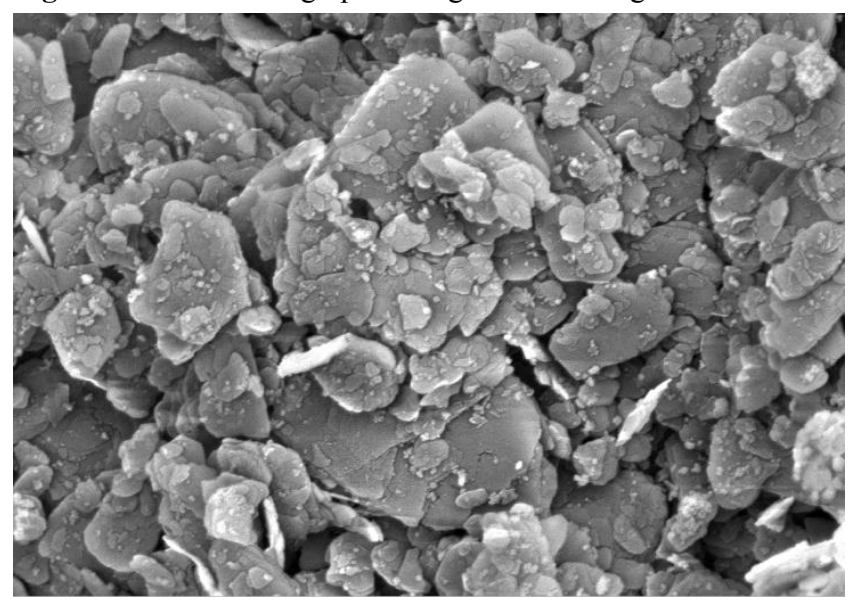

Fig. 11. FESEM micrograph of soil mixed with $1 \%$ lime: Mag $=20.00 \mathrm{KX}$.

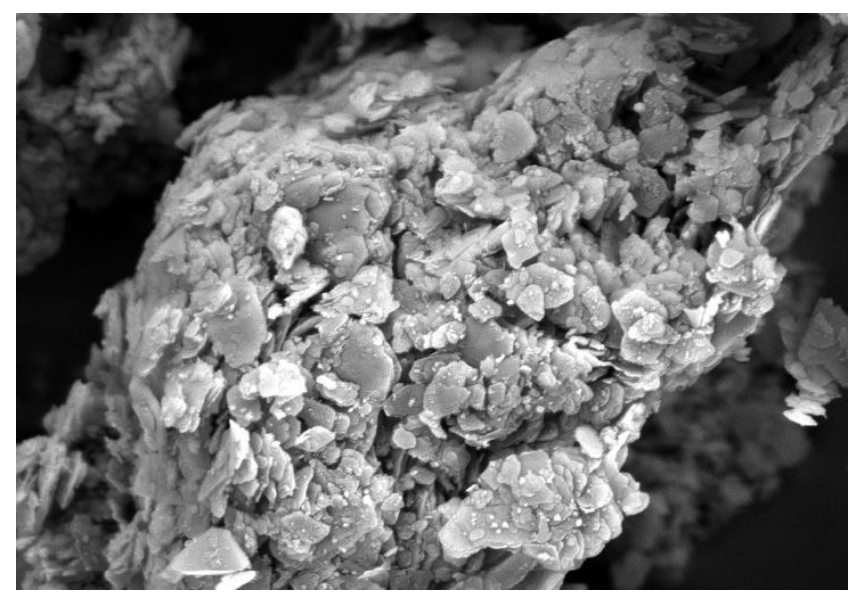

Fig. 12. FESEM micrograph of soil mixed with $1 \%$ nanolime: $\mathrm{Mag}=20.00 \mathrm{KX}$.

\section{Conclusion}

The PI of nanolime treated soil after 28 days of curing period exhibits significant reduction at 6.6 compared with the untreated soil at 12.3 . This reduction is in proportion with curing time and lime surface area (i.e. by using nanolime) as well as the doses of lime and nanolime. Meanwhile, the maximum dry density and optimum water content of the treated soil were higher than that of original soil. The maximum dry density was obtained for soil mixed with only $0.3 \%$ nanolime at 1 day curing period and $0.5 \%$ nanolime at 60 days curing period. Higher optimum water content was also obtained at this nanolime content. These results indicate that the stabilization mechanism of nanolime treated soil involved effective flocculation and agglomeration of soil particles by $\mathrm{Ca}^{+2}$ which bridges the negatively charged clay particles. The chemical reactions between the calcium oxides and dissolved silica present in the soil mineral are able to produce $\mathrm{CSH}$ gel for pozzolanic reactions. These flocculation and agglomeration between the soil particles could be seen clearly in the FESEM images of nanolime treated soil.

\section{References}

1. B.M. Das, Advanced Soil Mechanics: CRC Press (2013)

2. M.R. Hausmann, Engineering Principles of Ground Modification: McGraw-Hill (1990)

3. P. Weener, J.W. Holister, C. Román, T. Harper Nanoparticles: Technology White Papers, pp 3 (111) (2003)

4. M.R. Taha, Geotechnical properties of soil-ball milled soil mixtures. Berlin.: Springer, pp 3: 377382 (2009)

5. D. To, S. Sundaresan, R. Dave, Nanoparticle mixing through rapid expansion of high pressure and supercritical suspensions: J Nanopart Res., pp 13(9):4253-4266, doi:10.1007/s11051-011-0369-0 (2011)

6. J.R. Jones, D.J. Parker, J. Bridgwater, Axial mixing in a ploughshare mixer: Powder Technol, pp 178(2):73-86, doi: 10.1016/j.powtec.2007.04.006 (2007)

7. R. Yong, V. Ouhadi, Experimental study on instability of bases on natural and lime/cementstabilized clayey soils: Appl. Clay Sci., 35(3-4): 238-249 (2007)

8. M.R. Taha, O.M.E. Taha, Influence of nano material on the expansive and shrinkage soil behaviour.: Journal of Nanoparticle Research, pp 14(10): 1-13 (2012)

9. A. Lasledj, M. Al-Mukhtar, Effect of hydrated lime on the engineering behaviour and the microstructure of highly expansive clay: International conference on computer methods and advances in geomechanics (2008) 